\title{
Var en grænseændring mulig i 1946?
}

\section{Engelsk udenrigspolitik i det sydslesvigske spørgsmål}

\author{
af JARVin O. MellemgaARd
}

I september og oktober 1946 udvekslede England og Danmark to noter af afgørende betydning for grænselandet. Tilsyneladende tilbød England en grænseændring. I sit svar - den såkaldte Oktobernote af 19. oktober 1946 sagde Danmark imidlertid Nej. Men var der tale om et reelt tilbud? Cand. mag. Jarvin O. Mellemgaard, Kobenhavn, redegør her for den engelske politik, og gør sandsynligt, at en grænseflytning faktisk havde været mulig i 1946 - omend kun en begrænset regulering nordligst i Sydslesvig. ${ }^{1}$

\section{Indledning}

Da 2. verdenskrig sluttede i 1945, var det danske mindretal i Sydslesvig skrumpet ind til knap 3000 mennesker, primært koncentreret i og omkring Flensborg. Men fra 1945 til 1948 eksploderede mindretallet. I oktober 1948 var medlemstallet i den danske hovedorganisation SSF vokset til over 70.000 . Årsagerne til denne udvikling var en kombination af mange faktorer, men primært kan nævnes de mange flygtninge fra de tyske østområder, den store nød og elendighed i Tyskland og for mange en "genopvågnen « af danske sympatier og ønske om "genforening " med Danmark. Muligheden for en grænseregulering kom nu på dagsordenen både i Sydslesvig og i Danmark. I sagens natur blev det engelske udenrigsministerium Foreign Office (FO) inddraget i sagen, idet det stod som repræsentant for de engelske besættelsesmyndigheder i den nordlige del af Tyskland, der også omfattede Sydslesvig. Med det pludselig mangedoblede danske mindretal fandt de danske politikere det naturligt at intervenere $i$ den engelske besættelsespolitik, når den kom i konflikt med danske ønsker om frie udfoldelsesmuligheder for mindretallet. En sådan indblanding kunne englænderne imidlertid ikke acceptere. 

stre stod splittede i spørgsmålet, men mest hældede mod en folkeafstemning ad åre, omend for statsministerens vedkommende måske endda øjeblikkeligt om nødvendigt. ${ }^{4}$

Begivenhedsforløbet er behandlet gentagne gange i litteraturen. Lorenz Rerup kom i 1969 ind på emnet i »Grænsen. Fra grænsekamp til sameksistens «, mere grundigt blev det behandlet i Bjarne W. Frederiksens speciale fra 1971: "Danmarks Sydslesvigpolitik efter det tyske sammenbrud $i$ 1945«. Frederiksen beskriver levende den hjemlige opinion i de første efterkrigsår, og forsøger også at vurdere de engelske motiver i sagen. Dette besværliggøres dog af, at han ikke havde haft adgang til Foreign Office's arkiver. Han konkluderer, at der med septembernoten blot var tale om et skintilbud, og udelukker således, at englænderne reelt var til sinds at ændre på den dansk-tyske grænse.

Denne holdning gores der til dels op med i Johan Peter Noacks værk, »Det sydslesvigske grænsespørgsmål 1945-1947« fra 1991, hvor der gives en dygtig og kompetent analyse ud fra relevant arkivmateriale. Noack favner bredt og vil gerne have det hele med, både udviklingen i Sydslesvig, mindretallets foreninger, de danske politikere (her især Venstreregeringen) og den britiske politik, og bogen giver et godt billede af, hvad man kan kalde sydslesvigsk totalhistorie 1945-47. Han gør delvist op med Frederiksens tese, men tilslutter sig synspunktet om, at englænderne med deres kendskab til den parlamentariske situation i Danmark ikke reelt regnede med, at Danmark ville svare ja til grænseændringer.

\section{Optakten}

I januar 1946 var der gået otte måneder siden 2. Verdenskrig var sluttet i Europa. Man stod midt i den første efterkrigsvinter. I SlesvigHolsten var situationen som i resten af Tyskland og Europa for den sags skyld mildest talt kaotisk. Sydslesvig var kommet relativt ubeskadiget gennem krigen, men 300.000 flygtninge primært fra områderne øst for Oder-Neisse var blevet placeret $i$ landsdelen. ${ }^{5}$ I Danmark var opmærksomheden rettet mod det gamle land syd for grænsen. Mindretallet var fire-doblet $i$ antal siden krigens afslutning, men med de mange flygtninge så det ud til, at de nydanske dråber ville drukne i det overvældende tyske befolkningshav.

Sådan var situationen, da den danske udenrigsminister Gustav Rasmussen den 23. januar var $i$ London, hvor han mødtes med lede- 


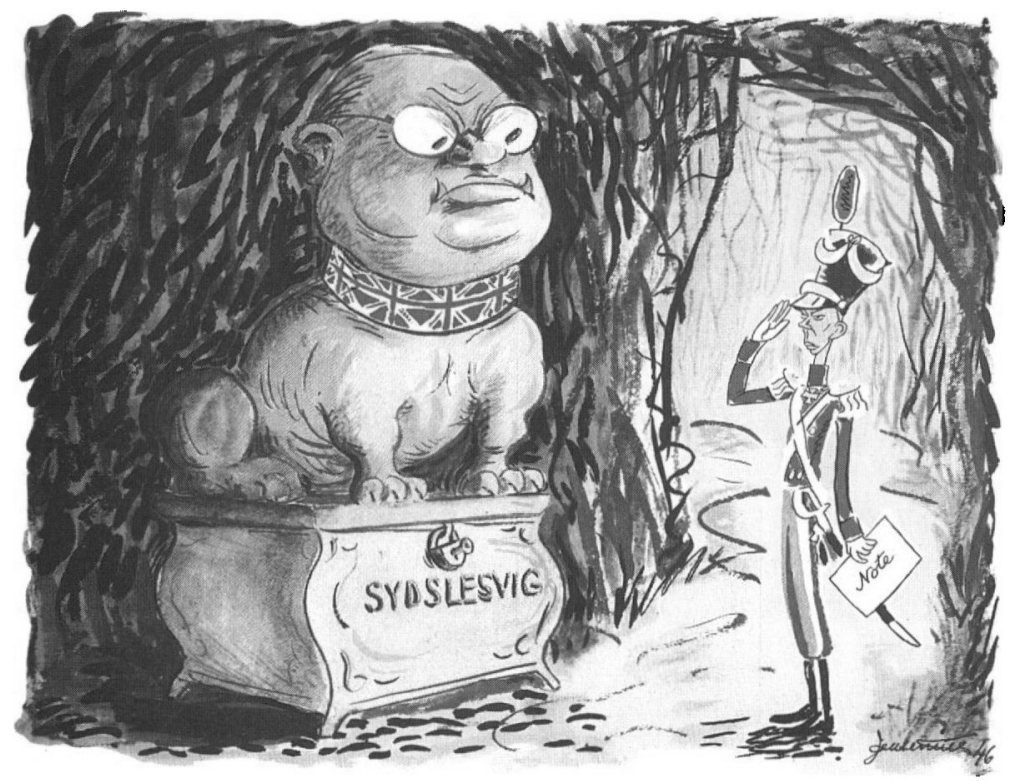

Den danske udenrigsminister Gustav Rasmussen drog til London med mange Sydslesvignoter $i$ drene efter krigen. Her kommer han - $i$ Jensenius' streg - marcherende og præsenterer sig for den britiske udenrigsminister Ernest Bevin. Blæksprutten 1946.

ren af Foreign Office, Orme Sargent. Foreign Office havde allerede inden mødet udarbejdet et internt memo, som forudså, hvad danskerne ville bede om. Af dette fremgår, at det skulle tilkendegives den danske udenrigsminister, at man fra engelsk side var åben over for et eventuelt dansk forslag omkring enten en befolkningsudveksling eller en grænseregulering med eller uden en forudgående folkeafstemning. Det var den officielle engelske holdning, som den danske udenrigsminister nu blev informeret om. Gustav Rasmussens svar var, at en befolkningsudveksling var udelukket, da der var for mange både emotionelle og økonomiske bånd $\mathrm{i}$ landsdelen, som $\mathrm{i}$ så fald ville blive brudt. Med hensyn til en folkeafstemning fastslog han, at det ikke var i den danske regerings interesse at afholde en sådan på daværende tidspunkt, da det blev vurderet, at en del vælgere grundet de øjeblikkelige omstændigheder i Tyskland ville stemme dansk uden at være danske. Han foreslog derimod, at man måske kunne afholde en folkeafstemning $\mathrm{i}$ landsdelen efter 5, 10 eller 15 år, når situationen var normaliseret. ${ }^{6}$ 
Det var ikke første gang en dansk regeringsrepræsentant blev stillet over for muligheden af grænserevision i Sydslesvig. Udenrigsminister Christmas Møller havde ved sit møde med Sargent i august 1945 bekræftet, at den danske regering fortsat stod ved sit udsagn fra 9. maj 1945 om at grænsen lå fast. I november 1945 var Udenrigsministeriets direktør Frants Hvass ved en samtale med lederen af Northern Department i Foreign Office C. A. Warner blevet adspurgt, om danskerne havde tænkt på at foreslå en grænseflytning. Svaret havde lydt, at det ønskede man ikke nu, men måske om 20 år. $^{7}$ De tre muligheder fremlagt af Sargent over for Rasmussen var således blot en gentaget formulering over for danskerne af den britiske Sydslesvigpolitik. I sin kerne byggede den på onsket om at undgå fremtidige mindretalsproblemer. Hurtigst muligt skulle grænserne lægges fast, mindretal skulle undgås og ligeså muligheden for moderlandes indblanding i mindretals anliggender. Hvad angår Sydslesvig ville det sige: dansk indblanding vedr. et dansk mindretal i Sydslesvig var uønsket. Dette skulle vise sig at være fast britisk politik frem til i hvert fald oktober 1946. Hvad der er tankevækkende er, at Rasmussen holdt det engelske udspil for sig selv. Ingen i Danmark - og slet ikke statsministeren - blev orienteret om denne mildt sagt vigtige engelske tilkendegivelse. I det referat, der blev forelagt Knud Kristensen, fremstår det, som om det var Gustav Rasmussen, der tog initiativet, og havde henstillet at man efter en årrække, når befolkningen var blevet nationalt afklaret i Sydslesvig, kunne skride til en folkeafstemning, som ville være mere pålidelig end en afholdt under de daværende omstændigheder. Først derefter havde, ifølge det danske referat, Sargent grebet ind og foreslået en befolkningsudveksling og kun det. ${ }^{8}$

Der er imidlertidig intet der tyder på, at samtalens forløb ikke er gengivet korrekt $\mathrm{i}$ det britiske referat, så der kan kun være tale om en bevidst fortielse, fordi referatet var bestemt for statsministeren. Dette underbygges yderligere af, at lederen af German Department, Jack Troutbeck, 16/4-1946 havde en samtale med den danske gesandt i London, grev Eduard Reventlow, hvor han gentog den engelske holdning. I følge eget referat (Troutbecks) lyttede Reventlow meget interesseret og ringede senere tilbage for at høre, om han måtte tage dette for officiel engelsk politik. Meget overrasket sagdé Troutbeck umiddelbart "nej« til dette, da han havde taget det for givet, at Reventlow var informeret af den danske udenrigsminister. Men efter at have sundet sig, meddelte han senere Reventlow, at dette var den 
officielle engelske politik på området. ${ }^{9}$ Reventlow sendte en depeche om denne samtale til Danmark. Det må nu være gået op for den danske gesandt, at Rasmussen ikke spillede med helt åbne kort. Men han valgte tilsyneladende at dække udenrigsministeren ved at gengive det godt indpakket, så det så ud, som om det kom som en stor overraskelse, at Troutbeck nu foreslog en grænseflytning. Men det fremgik dog, at grænseflytning var blevet nævnt som en mulighed. Rasmussen besluttede imidlertid, at statsministeren ikke skulle have Reventlows depeche at se, og dermed var det stadig kun en meget snæver kreds af danskere, der i foråret 1946 kendte FO's holdning i det sydslesvigske spørgsmål. ${ }^{10}$

Tilbudet om grænseflytning indgik altså i den engelske politik, og den 9. september blev det udtrykt i septembernoten med ordene, at "Hans Majestæts regering er derfor rede til at overveje ethvert forslag gaiende ud på enten en befolkningsudveksling, eller en folkeafstemning, efterfulgt af en grænseregulering, eller simpelthen en grænseregulering uden en forudgående folkeafstemning "." ${ }^{11}$

Hvordan kom det så vidt, at englænderne gav den danske regering et sådant memoire? I det følgende skal vi se, at der var flere årsager til dette. Indlysende og mest fremtrædende var man træt af danskernes indblanding $\mathrm{i}$ interne tyske forhold. Man kendte den parlamentariske situation i Danmark og regnede med, at danskerne ville afslå et udspil om grænseændring til gengæld for ikke-indblanding «. ${ }^{12}$ Men hvis danskerne mod forventning skulle være interesserede $i$ et af de tre forslag, var man klar til fra engelsk side at lade danskerne komme til fadet.

Men ud over den umiddelbare engelske irritation over den danske indblanding i de sydslesvigske forhold spillede også flere andre forhold ind, som måske hver for sig ikke berettigede et så vidtrækkende skridt, men som, når de sammenholdes, tydeligt politisk set gav baggrund for den engelske septembernote:

- Englænderne vidste ikke i 1945 og 1946, om amerikanerne ville blive i Europa lang tid efter krigen. England var i en sørgelig forfatning oven på krigen, og havde brug for alle de venner, det kunne få i dets bestræbelser på at opretholde en venligtsindet blok på kontinentet, som modvægt til den stærkt voksende kommunistiske blok af lande i Østeuropa.

- I forlængelse af dette var det nødvendigt at holde Danmark som en venligtsindet nation. Udenrigsminister Gustav Rasmussen var i 
gelske udenrigspolitik. I månederne frem til september 1946 forsøgte diplomaterne gennem mange samtaler at skaffe klarhed og dermed grundlag for en politik. 1/1-1946 telegraferede den britiske gesandt $i$ København, Alec Randall, til FO, at den danske statsminister havde udtalt, at regeringen anså Sydslesvig for dansk interessesfære, samt at den ville forsøge at få dette anerkendt af den engelske regering. ${ }^{14}$ Dette var samtidig en klar indikering af, at man langsomt fra dansk side var begyndt at fjerne sig fra "grænsen ligger fast«-udtalelsen fra maj 1945.

Som forberedelse til Gustav Rasmussens allerede omtalte besøg $\mathrm{i}$ FO i London den 23/1-1946 skrev Randall 14/1-46 et brev til FO, hvor han ridsede situationen i Danmark op i tre punkter:

1) Den offentlige opinion var de seneste uger styrket i retning af, at den danske regering skulle arbejde for, at Storbritannien ville lade døren stå åben for en fremtidig folkeafstemning i Sydslesvig. Dette, skrev han, kunne holdes $\mathrm{i}$ ave så længe Tysklands fremtidige status ikke var endeligt afgjort af sejrherrerne, men allerede nu måtte man forudse dansk pres på to områder, nemlig fjernelse af flygtninge fra Sydslesvig og administrativ adskillelse af Sydslesvig fra Holsten.

2) Skønt der var et element af nationalisme og ekspansionistiske tendenser at spore i den danske agitation, så ønskede danskerne Tyskland genrejst af kommercielle grunde, men de var samtidig oprigtigt bekymrede for magtbalancen i grænselandet, og så i flygtningene en potentiel trussel mod deres grænse, og støttede det danske mindretal $i$ et forsøg på at opretholde status quo etnisk set.

3) Han mente at have grund til at tro, at russerne uofficielt var blevet hørt om deres mening angående Sydslesvig, og at de havde sagt til danskerne, at de sympatiserede med de danske ønsker, og at den åbenlyse løsning ville være en bortflytning af det tyske befolkningselement. Han foreslog, at den danske udenrigsminister blev gjort opmærksom på, at det var netop denne fremgangsmåde $\mathbf{i}$ Polen, der var skyld i de mange flygtninges tilstedeværelse i Sydslesvig. ${ }^{15}$

Angående 1) så kom dette punkt i høj grad til at præge dagsordenen Danmark og England imellem i de næste 7 måneder. 2) Forstod man 
muligvis godt i FO, men man kunne ikke statte det, da det ville danne en uheldig præcedens $i$ andre grænseområder om man gav efter, og føjede dem i spørgsmålet om tilstedeværelsen af tyske flygtninge $i$ området. 3) Må siges at være en vigtig observation. Skønt intet tyder på, at det havde noget på sig, så har denne mulighed helt sikkert ligget lederen af FO Sir Orme Sargent $\mathrm{i}$ baghovedet under mødet med Rasmussen. Blot muligheden af, at der foregik en tilnærmelse mellem Danmark og Sovjetunionen, må have fået det til at løbe koldt ned ad ryggen i FO. Dette var stik mod alle engelske interesser. I FO's oplæg til mødet mellem Sargent og Rasmussen (dateret 22/1-1946) stod der: "Den danske regering har foran sig muligheden for enten at bede om en modifikation af den dansk-tyske grænse for på denne måde at få det danske mindretal indenfor de danske grænser, eller for at fă en befolkningsudveksling, hvor dette mindretal vil blive flyttet til Danmark. Den danske regering ønsker åbenbart ikke at bede om nogle af disse losninger, p.g.a. deres frygt for et stærkt Tyskland $i$ fremtiden, og de foretrækker at håndhæve deres ret til at beskytte det såkaldte mindretal. Et sådant minoritetssystem, er, med minoritetstraktaterne efter den sidste krig i erindring, præcis, hvad vi er fast besluttede på ikke at tillade efter denne. Det er blevet foreslået, at når den danske udenrigsminister kommer til møde i Foreign Office d. 23. januar, skal han informeres åbent om, at vores politik $i$ sporgsmålet folger ovenstående retningslinier, og at vi ser to forskellige muligheder for at lose sagen, men at vi ikke onsker at gøre os til fortaler for nogen af dem. ${ }^{16}$

Dette viser to ting; 1) englænderne vidste udmærket godt, hvad der indenrigspolitisk foregik i Danmark (skønt man ud fra Randall's rapporter tilsyneladende ikke var sikker på, i hvilken udstrækning der foregik tilnærmelser mellem Danmark og Sovjetunionen), og 2) man var ikke interesseret $i$ et dansk mindretal i Tyskland. Dette, sammenholdt med at Sargent allerede ved dette møde gav Rasmussen tilbuddet om grænseændring i Slesvig med eller uden foregående folkeafstemning (foruden alternativet om befolkningsudveksling), tyder på, at man på dette tidspunkt var fuldt til sinds at give Danmark Sydslesvig eller i hvert fald områder heraf. Endvidere var der tale om et officielt møde og ikke korridorsnak. Når formanden for det engelske udenrigsministerium (Sargent) foreslår den danske udenrigsminister at tænke over, hvilken statsretlig stilling han ønsker for Sydslesvig, må man antage, at der er tale om en reel mulighed, ikke om tom snak.

I FO skrev lederen af German Department, Jack Troutbeck, 14/5- 
46 til Sir William Strang i den britiske militæradministration i Berlin: "Sagen er, at deres [danskernes] syn på problemet er fuldstændigt forskelligt fra vores. De er åbenlyst frustrerede ved udsigten til, at deres lille mindretal bliver oversvømmet af denne horde af flygtende preussere. Og endnu mere er de bange for, hvad de tror dette vil betyde for dem $i$ fremtiden, hoor de forventer at komme til at opleve et stærkt pres for at flytte grænsen nordpå, så hele Slesvig endnu engang kommer under tysk styre. Det er derfor, de er så ivrige for, at der ikke må ske noget nu, som vil skade situationen til deres ufordel, og hvorfor de er så oprørte over offentlige udtalelser som f.eks. når løjtnant Lynden Bell taler om »nyslesvigere«. ${ }^{17}$ De ser på spørgsmålet under hensyn til, hvordan det på langt sigt vil påvirke deres nuværende grænse, hvorimod vi $i$ hovedtræk betragter det som et midlertidigt administrativt problem $i$ selve Tyskland. Muligvis nærer de en romantisk forestilling om deres fortid og er overnervøse over deres fremtid, men man kan ikke undgå at fole lidt sympati for dem. ${ }^{18}$

Han havde med andre ord godt fat i de bevæggrunde, danskerne havde for deres politik, og havde også forstået, at der lå andre end rent annektionistiske motiver bag danskernes handlemåder. Problemet for englænderne var bare, at uanset hvor meget forståelse man måtte have for Danmarks bekymringer og udenrigspolitiske mål, så var det som Troutbeck skrev ikke en politik, som passede sammen med den engelske. Men englænderne havde helt frem til afsendelsen af septembernoten det problem, at de ikke helt præcist vidste, hvad den danske politik var. Randall kæmpede en brav kamp i København for at få nogle klare tilkendegivelser. Således sendte han 15/5-46 et brev til udenrigsminister Bevin, hvor han refererede til en samtale, han havde haft med Gustav Rasmussen dagen for. Her havde Randall direkte spurgt Rasmussen, hvad det var, den danske regering og det danske folk ville have. Rasmussen svarede ham, at hvad Danmark onskede, var beskyttelse af mindretallets kulturelle rettigheder, fjernelse af alle flygtningene fra Sydslesvig, og sidst men ikke mindst at en folkeafstemning måtte overvejes meget nøje, inden englænderne en dag trak deres styrker hjem fra Tyskland.

Randall tilføjede i brevet: "Selv om udtrykket for denne nervøsitet hos nogle danskere dækker over nationalistiske og ekspansionistiske ambitioner, tror jeg det er en ægte nervøsitet for de fleste ansvarlige danskere, og det vil, tror jeg, seriøst skade engelsk-danske relationer, hvis vi undsiger det som ubetydeligt, eller nægter Danmark fulde muligheder for at vise en aktiv interesse $i$ Slesvigs fremtid. «19 Dette var længe Randall's linie; at man 
ikke måtte skade dansk-engelske relationer ved at underkende danskernes ret til at interessere sig for forholdene i Sydslesvig.

Grev Reventlows besøg hos Troutbeck i april, hvor Troutbeck forbløffet konstaterede, at det ikke lod til, at Reventlow havde hørt om de tre muligheder Sargent havde forelagt Rasmussen i januar (det vil sige de samme tre muligheder Danmark senere blev stillet overfor $\mathbf{i}$ septembernoten $)^{20}$, kan have givet englænderne et fingerpeg om, at dansk udenrigspolitik blev ført egenhændigt af Rasmussen og ikke af regeringen. Ingen direkte kilder fortæller, at de fangede denne vigtige detalje, men det kan have påvirket beslutningerne om at presse Danmark med septembernoten.

Randall advarede i et brev 14/6-46 FO om, at man ved at presse danskerne nu omkring Sydslesvigs status risikerede, at der rent faktisk kom et dansk flertal for en øjeblikkelig afstemning. Endvidere anførte han, at skønt der var ekspansionister i Danmark, så var flertallet kun interesseret $i$ at varetage danske sikkerhedsinteresser i Sydslesvig. ${ }^{21}$ Netop dette udsagn viser, at Randall måske uforvarende stod lidt med et ben $i$ hvert land, hvad angik synspunkter. For der var ikke noget, folkene i FO hellere ville høre end en klar dansk tilkendegivelse af, hvad man ønskede. Og det var ikke nødvendigvis et problem for dem, om man skulle presse danskernes synspunkt ud af dem, blot man fik synspunktet. Til et møde 1/7-46 sagde Rasmussen så til Randall, at Rigsdagen ville fremkomme med en resolution inden sommerferien, og denne ville for at tilfredsstille alle politiske partier blive "in most general terms «. ${ }^{22}$ Men Rasmussen mente, at den ville inkludere ønsket om at give folket i Sydslesvig mulighed for på et passende tidspunkt at udtrykke deres ønske om at blive forenet med Danmark. Randall understregede over for udenrigsministeren, at den engelske regering ville sætte pris på, at man konfererede med England, før man evt. tilnærmede sig de andre besættelsesmagter. Det vil sige, at England foretrak, at man så langt henad vejen som muligt behandlede sagen mellem England og Danmark alene. Rasmussen spurgte derefter Randall, hvad han troede, den britiske indstilling til en afstemning i et lille grænseområde ville være. Randall svarede, at han uden at kunne udtale sig officielt mente, at en sådan anmodning ville blive sympatisk studeret $i$ London. Der var sådan set ikke noget nyt i denne udtalelse fra Randall. Det var, hvad Rasmussen allerede i januar havde fået at vide af Sargent, da han var i London, men alligevel er det medtaget her, fordi meget tyder på, at det var en min- 
dre grænserevision, englænderne forestillede sig, og her forespurgte den danske udenrigsminister direkte om muligheden for en sådan.

Hvert et ord Randall sendte hjem blev læst grundigt, og taget med i overvejelserne frem til septembernoten. Ti dage senere gjorde Randall så endnu et forsøg på at hive nogle politiske standpunkter ud af den danske udenrigsminister. Om dette skrev han i et brev 15/7-46 til FO: "De bestræbelser jeg gjorde for at fă en præcis idé om det danske parlaments og regerings onsker med hensyn til fremtiden for Sydslesvig var ikke særlig succesfulde.« Han spurgte Rasmussen, om han måtte tolke Rigsdagsresolutionen "som en bandlysning af "grænsen ligger fast «-politiken, hr. Rasmussen svarede "nej", den udtrykte blot troen på selvbestemmelsesretten «. Randall fortsatte nok så vigtigt: "Jeg frygter, at agitationen vil fortsætte [i Danmark] indtil vi oprigtigt kan tilbyde Danmark muligheden for at teste mindretallets styrke $i$ Sydslesvig gennem en afstemning flygtningene undtaget - $i$ sådanne områder som synes at have et virkeligt og ægte onske om genforening med Danmark.«

Randall fulgte dette brev op med et til Strang og Steel i den britiske militæradministration i Berlin dateret d. 19/7-46. Heri beskrev han situationen i Danmark som spændt: "Vi er nu udsat for en strom af propaganda på grund af vores påståede uvenlighed over for Danmark og vores komplette misforståelse af hele det slesvigske problem «. ${ }^{23}$ Det var et forsøg på at presse Strang til en lidt mindre fjendtlig attitude over for mindretallet, medens man ventede på den afklaring, alle vidste snart måtte komme. Dette understregedes af, at Sargent fra FO 6 dage efter sendte et brev til Strang og Steel i Berlin, hvori det hed, at alle danske ønsker angående Sydslesvig så vidt muligt skulle imødekommes, hvis det ikke var i fuldstændig modstrid med britisk politik, samt at man i sager, hvor man ikke kunne imødekomme danskerne, skulle forklare dem dette "fuldt og overbevisende «. ${ }^{24}$ Det var i disse dage i juli 1946 at den danske indflydelse (om man så ville have den eller ej) iSydslesvig efter 2. Verdenskrig toppede. Fra chefen af det engelske udenrigsministerium udgik direkte ordre om, at alle mulige (og umulige) hensyn skulle tages til Danmark, hvad angik forholdene i Sydslesvig. Brevet er skrevet 13 dage for mødet, hvori septembernoten skabtes, og viste, at hensynet til Danmark på dette tidspunkt vejede endog meget tungt i England. Dette skyldtes ikke kun hensynet for det svækkede England om at skaffe sig allierede som modvægt til Sovjetunionen, men også ønsket om at få forsyninger af danske landbrugsprodukter til en pris under Verdensmarkedsprisen i sommeren $1946 .^{25}$ 

det danske mindretal. Det var dette administrationen i Berlin hele tiden havde advaret mod ud fra en betragtning om, at det kunne danne en farlig præcedens ved de tyske grænser mod kommunistiske naboer. Således skrev Strang fra Berlin 19/7-46: "Hvis vi en bare én gang begynder at forhandle, vil foreningen (SF) [mindretallets hovedorganisation Den Slesvigske Forening] overhovedet ikke gå med til noget uden at hore Kobenhavn forst. Dermed kommer vi i realiteten til at forhandle med en udenlandsk regering om, hvordan vi skal behandle en del af den tyske befolkning. Dette vil danne en præcedens, som andre regeringer - især den polske - må forventes at gribe (det er vard at bemærke, at polske og jugoslaviske diplomater $i$ Tyskland på det seneste har vist interesse for tyskere af polsk og jugoslavisk afstamning). ${ }^{27}$ Lige præcis dette synspunkt forklarer, hvorfor der gennem hele 1946 foregik en intern kamp mellem engelske diplomater i Berlin og Kobenhavn. Den erfarne Strang i Berlin tillagde ikke Danmark samme betydning som FO i London og gesandt Randall i København. For Strang var det afgørende, at man ikke grundlagde nye stridigheder, der kunne lægge kimen til en ny krig, som Versaillestraktaten havde lagt til 2. Verdenskrig med dens mindretalsbeskyttelser, og hans hovedargument var hele tiden, at det ville skabe en farlig præcedens, hvis den danske regering mere eller mindre indirekte blev hørt, når briterne skulle træffe beslutninger vedrørende Sydslesvig. Egentlig havde han vel ikke de store problemer med at give det danske mindretal rettigheder, når det nu ikke kunne være anderledes for at tilfredsstille den danske regering - men ikke hvis disse rettigheder kom til at danne præcedens for andre mindretal, da mindretal generelt efter krigen blev betragtet som et onde i modsætning til efter 1. Verdenskrig.

Englænderne i Berlin udarbejdede i foråret 1946 en efterretningsrapport omkring mindretallet $\mathrm{i}$ et forsøg på at fastslå danskhedens styrke i Sydslesvig. At 2.556 medlemmer i maj 1945 var steget til 25.323 medlemmer 1/4-1946 blev trukket frem. Og det konstateredes, at der nu (1/6-1946) var over 30.000 medlemmer. Dette antal måtte dog forventes at falde til ikke over 20.000, når de nye medlemsregler trådte $\mathrm{i}$ kraft, regler der sagde, at medlemmer eller deres forældre skulle have været medlemmer af SF før 1/1-1946. Omkring »rekrutteringsmetoderne " hed det $\mathrm{i}$ rapporten: "Selv om der har været isolerede eksempler på overentusiasme, har foreningens officielle holdning været tilbageholdende og korrekt.« Der anførtes fire hovedårsager til at befolkningen indmeldte sig: 
"a) En xgte folelse af slægtskab med Danmark snarere end Tyskland kombineret $i$ mange tilfxlde med antipati over for flygtningene fra andre dele af Tyskland.«

b) Ønsket om at opnå de materielle fordele som et medlemskab af SF indebærer

c) Ønsket om at komme af med flygtningene; indlemmelse $i$ Danmark synes for mange at være den eneste mulighed for at opnå dette.

d) Ønsket om at undgå konsekvenserne af Tysklands krigsskyld.

Andelen af nye medlemmer inspireret af ægte folelser for Danmark er uden tvivl betragtelig, men de andre tre grunde har draget mange til at melde sig ind $i$ SF, som ingenting kender til Danmark eller dansk kultur, og som aldrig for har vist interesse for danskheden.«

I en delkonklusion hed det: "Det er umuligt at bedømme præcist, $i$ hvilket omfang Slesvigsk Forenings øgede medlemstal skyldes de lokkende madrationer ... for mens der ikke kan herske toivl om, at mange mennesker der ikke ellers ville have meldt sig ind $i$ foreningen, er blevet tilskyndet til det af løftet om - eller $i$ de seneste medlemmers tilfxlde håbet om - ekstra madrationer, er det lige så sikkert, at mange af de nye medlemmer altid har haft danske sympatier, men at de grundet tysk pres, eller egen mangel på entusiasme, har ladet disse undertrykke til fordel for de materielle fordele det indebar at afsværge danske forbindelser. ${ }^{28}$ Rapporten blev udsendt til alle relevante instanser, også til topledelsen, og må have haft en vigtig rolle rent informationsmæssigt for de personer, der senere var med til at vedtage septembernoten.

I et brev af 2/8-1946 til FO i London skrev Steel bl.a.: "Det står stadig $i$ vente at se, om befolkningen $i$ Sydslesvig ved valget vil stemme på de traditionelle partier, eller om de vil lade dem i stikken til fordel for de materielle fordele Sydslesvigsk Forening stiller dem i udsigt. Men det står klart, at foreningens energiske kampagne for at få ægte tyskere til at g̊̊ ind $i$ mindretallet, har affedt en alvorlig reaktion blandt de politiske partier, og vi står nu over for, hvad der kan vise sig at være begyndelsen på et meget alvorligt mindretalsproblem, hvilket præcis er, hvad vi hele tiden har været ivrige efter at forhindre. ${ }^{29}$ Det var som om den eksplosive udvikling i 1946 kom bag på ham, som om han ikke havde forudset, at det lille danske mindretal kunne udvikle sig til andet end en kuriositet. Men hans advarsler mod spændinger mellem tysk- og dansksindede sydslesvigere var noget, som Randall i starten af august også havde været inde på i sit brev til premierminister Clement Attlee ${ }^{30}$, og disse 
arbejderklassen og den lavere middelklasse, er foreningens politiske holdning til indenrigspolitiske affxer (for så vidt som det overhovedet giver mening at tale om SSF som et politisk organ) tættest pd de synspunkter som repræsenteres af SPD og FDP. Men siden grænsespergsmålet stadig er fuldstændigt dominerende $i$ det politiske liv i Sydslesvig, er det usandsynligt, at noget effektivt samarbejde mellem SSF og de tyske partier vil finde sted, undtagen på rent lokale spørgsmål, indtil sporgsmålet om grænseændringer glider $i$ baggrunden. « ${ }^{30}$ Her fremstod SSF altså som et parti, der splittede, og dermed destabiliserede Sydslesvig. Man forstår Steels indvendinger mod at give det lige rettigheder med de øvrige partier. Men da oktobernoten ${ }^{31}$ blev kendt et par dage senere, var det for FO i London (og for Steel i Berlin for den sags skyld) lige pludseligt et mindre problem at have et separatistisk parti i Sydslesvig. Uden støtte til sine grænsekrav fra Danmark var SSF for englænderne blot et lille lokalt tysk parti. Fra nazisterne var man vant til lidt af hvert inden for politisk retorik, og når SSF ikke havde det officielle Danmark i ryggen, var deres stærke agitation kun ord fra en gruppe mennesker i en besejret nation under militæradministration.

\section{Frygten for Sovjet}

Hvilken rolle spillede det engelske ønske om at holde Sovjetunionen uden for indflydelse for tilblivelsen af septembernoten? Grundlæggende står det klart, at den store indflydelse, Danmark blev tildelt af England i det sydslesvigske spørgsmål, i vid udstrækning var affødt af ønsket om at binde danskerne tættere til England. Ligeledes er der ingen tvivl om, at man i London var nervøse for en evt. udvikling over mod et tættere forhold Danmark og Sovjetunionen imellem, samt at man ikke var helt sikker på, hvad der foregik mellem de to lande.

Randall var opmærksom på muligheden for dansk-sovjetisk tilnærmelse. I et brev til FO, hvor han redegjorde for danske forhold som oplæg til mødet mellem Sargent og Rasmussen d. 23/1-46, skrev han, at der var grund til at tro, at der foregik en tilnærmelse mellem Danmark og Sovjetunionen i Sydslesvigsagen. ${ }^{32}$ Han gentog advarslen efter Rasmussens ophold i Moskva i juni 1946 (i brev til udenrigsminister Bevin 27/6-46) ${ }^{33}$, og han sørgede også for, at FO d. 10/6-46 fik at vide, at dansk presse mente at disse tilnærmelser var sket. ${ }^{34}$

Randall var - for FO - at betragte som den bedste informationskil- 
de omkring dansk-russiske forhold. Han vurderede 15/4-1946 i et "privat og fortroligt « brev til lederen af Northern Departement R.M.A. Hankey de danske motiver som følger: "Sagen er, at alle danske offentlige udtalelser med hensyn til Rusland omkring vores tropper her, har, som jeg mere end en gang har påpeget, været dikteret af taktiske overvejelser ... et lille land som dette, desperat for at holde sig ude af enhver konflikt, og $i k k e ~ i$ stand til at forsvare sig selv mod en stormagt ... vil altid reagere på denne måde. Denne politik fik overordnet set Danmark nådigt gennem den tyske besættelse, under hvilken landet led forholdsvist lidt, men ikke desto mindre drog fuld fordel af det udviste mod og dygtighed fra den meget lille modstandsbevægelse til at blive anerkendt som en kæmpende allieret. Indtil der eksisterer en modvægt til den russiske indflydelse i Danmarks nærområde, med andre ord indtil Tyskland er genrejst, vil vi, tror jeg, være nødt til regne med denne taktiske opførsel. Dette burde ikke, vil jeg tilføje, ændre pð̊ den kendsgerning, at Danmark fundamentalt set er et vestligt land og en ægte beundrer af britiske institutioner, og også fast tilknyttet til de demokratiske principper som vi selv tror på. ${ }^{35}$

Randall brugte brevet til at fremhæve, at danskerne måske nok var svære at forstå, men at de var på Englands side. Randall sendte to og en halv måned senere - på et tidspunkt hvor alle kræfter i FO arbejdede hen imod et ultimatum til Danmark vedrørende Sydslesvig - et memorandum til udenrigsminister Bevin, der beskrev Danmarks og danskernes forhold til Sovjetunionen. I dette hed det: "Selv den engelskuddannede og vestligsindede minister $i$ den nuværende danske regering, Per Federspiel, har argumenteret mod den massive markedsmæssige forbindelse mellem Danmark og Vesten, og formentlig ville flertallet af den danske befolkning virkelig gerne se en storre udveksling af varer med Rusland; nogle ville ikke finde muligheden uvelkommen for i prissporgsmål at spille Storbritannien ud mod Rusland og omvendt. De fleste er klar over, at østmagten ikke markedsmæssigt i længden kan sikre Danmark den samme form for sikkerhed som Storbritannien med hensyn til afsxtning af landbrugsprodukter, men så længe Tyskland er ude af billedet, er Rusland den eneste modvægt mod at putte alle æg $i$ en kurv, hvilket danskerne ser som at gare deres økonomi for sårbar. Dette har også en politisk side. Det er unodvendigt at betone, at efter befrielsen og især efter tiltrædelsen af den nuværende danske regering - samt også p.g.a. traditionelle danske interesser $i$ Sydslesvig, er det politiske kommet $i$ fokus. I denne sammenhæng er den britiske administration af den britiske zone uheldigvis impliceret, og der er mange danskere, der mener, at de vil blive bedre hørt i denne sag, hvis de kan fă russerne til 
at gå ind $i$ sagen. Muligheden for, at selv den danske regering vil folge en sådan politik $i$ nær fremtid, kan ikke udelukkes, mens jeg skriver dette, og det er unødvendigt for mig at fremheve, hvilke politiske konsekvenser enhver aktiv russisk involvering $i$ den danske nationalistiske sag vil betyde. Jeg er bange for, at dette ikke er sidste gang, det bliver nødvendigt for mig at henlede opmærksomheden på dette emne. $^{36}$

På dette tidspunkt må denne karakteristik have givet genlyd i London. Randall var den engelske ekspert, hvad angik Danmark. Når han vurderede, at der var en reel risiko for, at danskerne ville vende sig til Sovjetunionen i det sydslesvigske spørgsmål, måtte man foretage sig noget $i$ London. Han understregede, at Danmark fundamentalt var vestligt orienteret med de samme værdier som England, men at problemet lå i Danmarks traditionelle neutralitetspolitik: "Alle danskere, uanset om de har ostlige eller vestlige sympatier, håber, at de på en eller anden måde, enten ved dygtighed eller held, vil være $i$ stand til at undga at komme i en situation, hvor de bliver tvunget til at vælge mellem Øst og Vest.«I samme åndedrag advarede han mod »alt hvad der kan gøre Rusland $i$ stand til, med en hvis plausibilitet, at pege på Danmark som et "britisk lydland"«. Jo dygtigere dette kunne undgås "jo mere effektivt vil vi være $i$ stand til at samarbejde med Danmark $i$ at fremme de vestlige politiske og sociale idéer, som er en essentiel del af dansk mentalitet, og som Storbritannien bliver set op til som den eneste stærke beskytter af «. ${ }^{37}$

Som ambassadør i Danmark blev Randall antaget at besidde et bedre kendskab til danske forhold end nogen anden i FO. Derfor må det være blevet tillagt en enorm betydning i London, at man skulle undgå en situation, hvor danskerne vendte sig til russerne $\mathrm{i}$ håb om at blive bedre hørt her omkring Sydslesvig. En sådan situation ville ud over et stort prestigetab for englænderne medføre en ændret magtbalance i Nordeuropa. Randall's opskrift på at undgå et sådant skrækscenario var simpel; man skulle lade danskerne fore deres balancepolitik. I det lange løb ville den være i Englands favør. Og så skulle man høre på dem, så de kunne mærke, at man lyttede, når det gjaldt Sydslesvig. Randall påpegede også, at Danmark på langt sigt ville være nødt til at orientere sig mod England rent markedsmæssigt, så $\mathrm{i}$ bund og grund handlede det om en ting for London: At sørge for at danskerne ikke blev stødt eller følte sig uværdigt behandlet af englænderne.

Hermed var der også givet et godt motiv til englænderne for at udforme septembernoten. Hvis der var en fare for, at danskerne ville 
vende sig mod russerne $i$ håb om at få en bid af landsdelen, kunne englænderne lige så godt eliminere denne mulighed ved selv at tilbyde danskerne dette.

\section{Overvejelser i Foreign Office}

Randall skrev 14/6-46 til FO, at man ved at presse danskerne i spørgsmålet om Sydslesvig ikke kunne udelukke, at et flertal af danskerne ville støtte ideen om en øjeblikkelig folkeafstemning i Sydslesvig. Men netop dette foruroligede ikke FO. Her ville man ikke have at Randall afviste "any Danish idea which may develop «. En intern kommentar fortsatte: "I lyset af de konsekvenser en senere folkeafstemning vil have (ustabilitet $i$ landsdelen etc.), bor vi kun gå med til en afstemning $i$ en meget nær fremtid, $i$ så tilfælde vil det også være muligt at sammenkæde den med en befolkningsudveksling, således at de danske i Sydslesvig bliver placeret $i$ Flensborg med omegn - hvis dette område bliver indlemmet $i$ Danmark. Dette vil også fjerne den danske frygt for deres "naboer og fjerne de fleste af Danmarks undskyldninger for at blande sig $i$ sydslesvigske forhold. Det er dog meget usandsynligt, at de vil medvirke til en sådan løsning." Endvidere skrev lederen af German Department, Patrick Dean, 4/746 til Randall: "Vi tror ikke, nu da doktrinen om den faste grænse er blevet forladt, at der er nogen grund til at råde danskerne imod, i nær fremtid at komme med - til os $i$ forste omgang - konkrete forslag angůende en mulig grænseændring eller en folkeafstemning. $\ll^{38}$

Der var her tale om to topembedsmænd i FO i London, som begge mere end antydede - den ene endda over for den britiske ambassadør i Kobenhavn - at man gerne så grænsen flyttet, blot det blev i nær fremtid. Samtidig viser udtalelserne, at man var lidt $i$ vildrede om, hvad danskerne egentlig ønskede. Brevet fra Dean til Randall kan meget vel have været en af de faktorer, der afstedkom Rasmussens voldsomme julitale ${ }^{39}$, da Randall har haft Deans instruktioner i baghovedet under sine samtaler med Rasmussen. Dean gav her endvidere udtryk for, at det var FO's ønske, at Randall støttede den danske udenrigsminister i dette spørgsmål. Der er intet her, der tyder på andet end, at det $\mathrm{i}$ juni/juli var officiel engelsk politik, at man ønskede et dansk udspil, en »ønskeseddel«, man kunne opfylde. Dette var ikke et spil for galleriet. Der var tale om tophemmelige drøftelser internt $i$ det engelske diplomati.

Der var mange ideer til, hvordan man skulle løse problemet. I FO 
skrev Brown et internt memo d. 20/6-1946: »Vi har altid fastholdt, at det sydslesvigske spørgsmål udelukkende hører under den britiske regering, inklusive flygtningeproblemet. Det samme synes at være gxldende hvad angår en folkeafstemning eller en grænseændring. Så vidt jeg ved, er sporgsmålet om en mindre grænseændring ved den tysk-hollandske grænse ikke blevet behandlet af alle fire magter, men er udelukkende blevet behandlet som en sag mellem den hollandske og den britiske regering. Det samme synes jeg, bør være gældende $i$ den danske sag. " $"$ "0

Han fik svar på tiltale af sin overordnede Dean d. 22/6-1946, der skrev, at spørgsmålet om en grænseændring mellem Danmark og Tyskland var et spørgsmål, der måtte tages op af de allierede som helhed, men at det ville være bedst, om Danmark først kunne formulere et krav til Storbritannien, som så kunne tage det videre til det allierede Kontrolråd for Tyskland. Dette synspunkt fik tilslutning af FOs direktør Sargent, efter at han havde læst Randall's indberetning om mødet mellem ham, Rasmussen og den amerikanske ambassadør i København, Marvel. Men Sargent skrev også, at en sådan anmodning fra dansk side formentlig "vil blive behandlet med hensyn til de mindre justeringer af den hollandsk-tyske grænse, som for tiden bliver diskuteret mellem den hollandske og den britiske regering " ${ }^{41}$ Disse drøftelser endte med en mindre grænserevision $i$ hollandsk favør, og der er intet i Sargent's udtalelser her, der tyder på, at han ikke mente, at en dansk anmodning ville modtage samme behandling af de allierede. ${ }^{42}$

Forslaget om befolkningsudveksling eller grænseændring blev også bragt frem for den danske gesandt grev Reventlow. ${ }^{43}$ D. 29/6 foreslog C. A. Warner i Northern Department, at man gav Danmark et lille område, hvor alle dansksindede sydslesvigere samledes, mens de tysksindede i området skulle udvises. Reventlow svarede ham, at den danske regering ingen sådanne planer havde for øjeblikket, hvortil Warner svarede, at det i så fald var et »oplagt tidspunkt at tænke $i$ de baner «. ${ }^{44}$ Endnu en indikering af, at man fra engelsk side ventede på et dansk udspil i slutningen af juni og starten af juli 1946.

Dean skrev på omslaget af sagen fra Randall angående Rasmussens forudsigelser om julitalen dateret d. 6/7-1946: "Det synes oplagt, at vi ret snart vil nå et punkt, hvor vi bliver nodt til at beslutte, om det vil være til vores fordel snart at få en folkeafstemning $i$ områderne lige syd for grænsenforudsat at vi kan sørge for, at de mange flygtninge ikke fär indflydelse på en sådan afstemning - eller om vi skal tillade, at dette sporgsmål bliver ved med at stå abent, som danskerne synes at foretrække, indtil forholdene $i$ 
området er blevet så normaliserede, at en ægte folkeafstemning kan afholdes. Personligt foretrækker jeg den forste losning, skont jeg til dels forstår danskernes holdning. Jeg mener ikke, at den danske regering kan forvente, fortsat at have sagen kørende på deres præmisser. ${ }^{45}$ Dean var næstkommanderende i FO og dermed absolut ikke hvem som helst. Nu ventede briterne kun på det danske udspil.

Hvis Danmark i juli 1946 havde ønsket Flensborg med omegn inkorporeret i Danmark, ville England have sat al deres indflydelse bag et sådant dansk ønske, især hvis det kom fra danskerne selv og ikke som et forslag fra briterne.

\section{Septembernoten}

Septembernoten blev i realiteten til allerede d. 7/8-1946. Denne dag var der møde i London mellem repræsentanter for de øverste britiske myndigheder fra England, Tyskland og Danmark. Noten blev finpudset flere gange i løbet af den næste måned, men der blev ikke tilføjet afgørende ændringer $\mathrm{i}$ forhold til det oprindelige udkast. Den indeholdt for så vidt ikke noget nyt, i og med at den blot gentog over for Danmark, hvad der populært udtrykt hele tiden havde været FO's holdning: "Enten tager I selv ansvaret for Sydslesvig, eller også lader I os gøre det i fred. « Det eneste nye var, at den danske regering nu blev tvunget til at klargøre sin stilling officielt. Dette var enden på et langt spil mellem danskerne og englænderne. For offentligheden havde det set ud som om, englænderne ikke havde givet den danske regering klare retningslinier at forholde sig til. Denne illusion havde den danske regering selv dygtigt skabt. Men med septembernoten forelå der et klart udspil, og regeringen blev nødt til at komme med en offentlig erklæring. Skønt englænderne i realiteten havde en mere end god idé om, hvad svaret på noten måtte blive, formulerede de noten, som om de ikke havde den fjerneste idé om, hvad den danske regering ville svare.

Dagsordenen for mødet 7/8 var næsten identisk med en rapport udarbejdet af Rodney Gallop fra Research Department. ${ }^{46}$ Denne er dateret 24/7-1946, men er først registreret i FO's arkiv d. 26/8-1946. ${ }^{47}$ Brown i FO har læst den 3/8-1946, hvilket er samme dag som mødedagsordenen for mødet 7/8-1946 er udformet, og skrev på omslaget: "Et møde er arrangeret for at diskutere alt dette $d$. 7. august. « ${ }^{48}$ Gallop beskrev i rapporten dansk mentalitet og dansk-engelske relationer, som de oplevedes af en englænder i Danmark i sommeren 1946. Han 


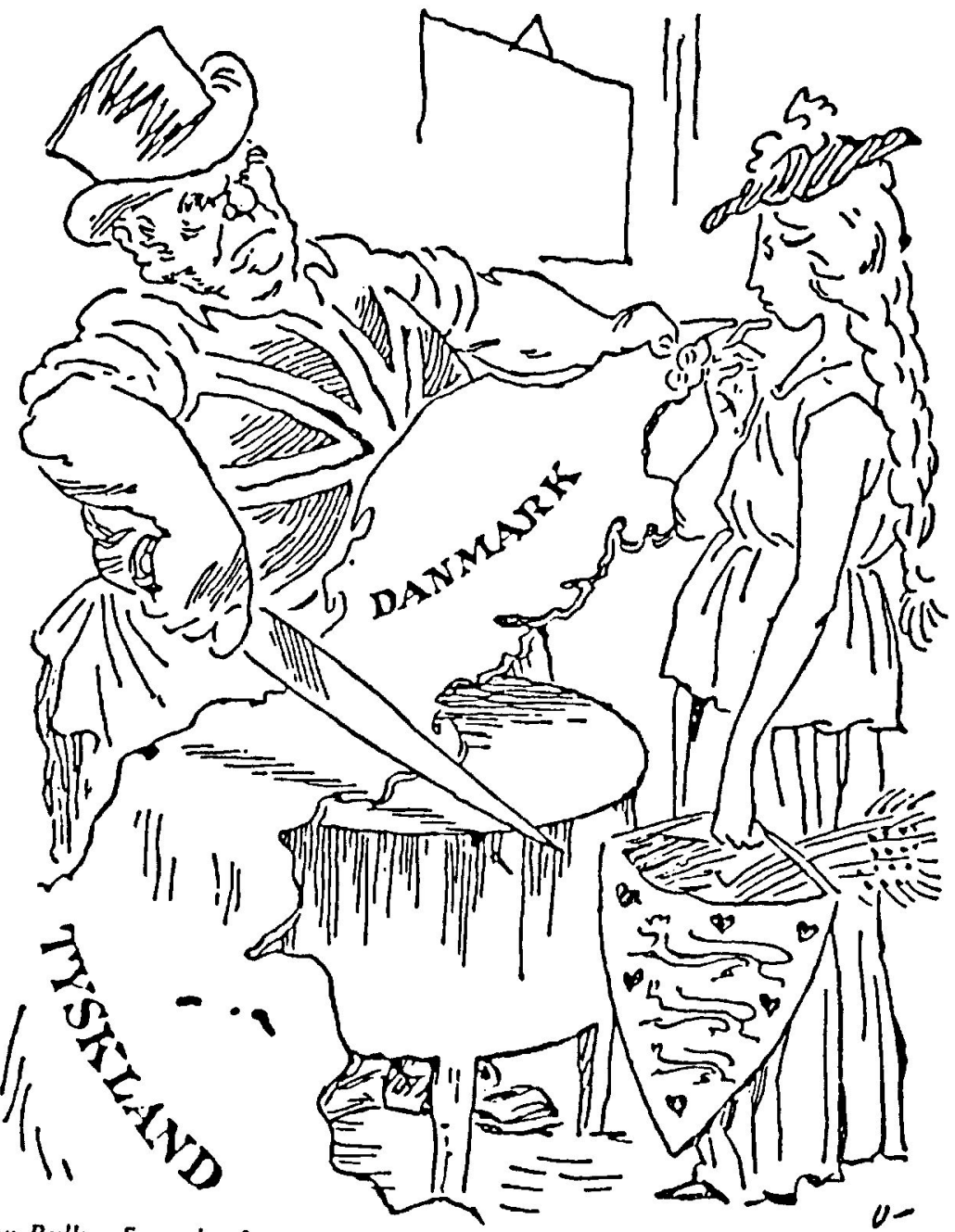

John Bull: - Say when?

Septembernoten indeholdt tilsyneladende et tilbud om deling af Sydslesvig. Arne Ungermann har noget overdrevet illustreret det med denne tegning 14. september 1946.

var uden tvivl blevet bistået af Randall, som ved andre lejligheder demonstrerede stor indsigt $\mathbf{i}$ dansk mentalitet, for rapporten viste $\mathbf{i}$ høj grad forståelse for, hvad der på dette tidspunkt rørte sig i Danmark, og hvad danskernes bevæggrunde $\mathbf{i}$ hele Sydslesvigsagen var. Han (Gallop) beskrev, hvorledes englænderne, da de først ankom til 
Danmark som befriere, mødtes med en kæmpe goodwill. Men da danskerne af natur er kritiske, kunne englænderne ikke hvile på laurbærrene for evigt, og nu var man ved at få et problem angående Slesvig: "Det slesvigske spørgsmål har dybe rødder $i$ deres nationale bevidsthed, og der har fra første færd været en fare for, at en dårlig håndtering fra vores side ville få seriøse konsekvenser for det engelsk-danske forhold. " Med henblik på anglo-danske relationer måtte man aldrig glemme "to permanente langsigtede faktorer; landets geografiske placering og indbyggernes mentalitet.«

Rapporten beskrev Danmark som wet lille fladt og meget sårbart land, liggende præcis på den linie der deler Øst-og Vesteuropa ... Indtil nu har relationerne mellem Sovjetunionen og de vestlige magter resulteret $i$ langt mere tilfredsstillende forhold $i$ Nordeuropa end $i$ sydøst. Dette fortsætter måske, måske ikke. $\mathrm{Og}$ England »har formentlig ikke råd til at glemme muligheden for, at spændingerne $i$ sydøst kan sprede sig til nord, med det resultat - hvis ikke krig - at der i hvert fald bliver god del taktik omkring interesser $i$ området, og her har Danmark en nogleposition." Skulle det værste ske (russisk invasion af Danmark) "vil passiv og aktiv dansk modstand igen blive et værdifuldt aktiv.« Men der var også et andet og mere håndfast argument for at bevare et godt forhold til Danmark, nemlig det økonomiske: "Vi er afhængige af dansk goodwill, så længe vi ikke er parate til at konkurrere med alle andre købere $i$ de priser vi tilbyder danskerne for deres madprodukter.«

Om den danske holdning til Sydslesvig skrev han, at den handlede om andet end traditionel aggressiv ekspansionspolitik: "At betragte den danske holdning til Sydslesvig og dets danske mindretal som et simpelt udtryk for national chauvinisme, og at tro, at man kan ændre grænserne og/ eller udveksle befolkningen efter samme retningslinier som foretaget $i$ andre dele af Europa, er en farlig og vildledende forenkling. " Motivet skulle snarere søges $\mathrm{i}$ den traditionelle forsigtige danske udenrigspolitik (grundet landets placering): »Den »midt på vejen « danske holdning er grundlæggende fornuftig, og det vil være farligt for os at overse denne kendsgerning, uanset $i$ hvor høj grad vi er $i$ stand til at imødekomme danske ønsker."

Det er vigtigt her at bemærke, at Gallop havde forståelse for den frygt, danskerne nærede for de mange flygtninge i Sydslesvig, og forstod, at danskerne med mellemkrigstiden in mente havde grund til at frygte et fornyet pres på grænsen, når Tyskland atter blev stærkt. Dette udtrykte rapporten således: »Danmark er interesseret $i$ Sydslesvig udfra folgende motiver: (i) det er den del af Tyskland der ligger tættest p̊̊ 
Danmark, (ii) en bufferzone mellem Danmark og hvad jeg - $i$ mangel af et bedre navn - vil kalde det rigtige Tyskland, (iii) eksistensen af et antal mennesker som er danske enten sprogligt eller $i$ sindet eller på anden måde er af dansk afstamning. Danskerne er dybt og legitimt bekymrede over, hvad de betragter som en centrifugal ekspansionisme fra Tysklands side. De mener, at vi lever $i$ en ny folkevandringstid, og at tyskerne, på langt sigt, vil brede sig udover de eksisterende nordlige og vestlige grænser af Tyskland. Det er derfor nemt at forstå deres frygt for det store antal tyskere, som nu er ankommet til Sydslesvig, og som truer med at ændre landsdelens etniske balance og karakter. Den ideelle situation for danskerne i denne sammenhæng ville være, hvis man kunne opretholde status quo. Det danske mindretal er stærkt knyttet til deres hjem, og stærkt imod enhver snak om befolkningsudveksling, men de ville hilse en grænseændring velkommen. Danmark derimod, stritter kraftigt imod tanken om at indlemme et område med et nyt og potentielt disloyalt [tysk] mindretal indenfor landets grænser. Besættelsen har bestyrket danskerne $i$ deres opfattelse af værdien af at leve i en ægte nationalstat. De ønsker ingen grænseændringer pd̊ nuværende tidspunkt, hverken med eller uden en forudgående folkeafstemning, da en sådan under de nuværende omstændigheder abenlyst vil blive mere paivirket af opportunisme end af ægte nationale sympatier. Hvad danskerne derimod virkelig onsker, er fjernelse af de mange flygtninge fra landsdelen snart, og indtil det sker, at flygtningene ikke fär de politiske rettigheder, som de lokale indbyggere nyder. Derudover ønsker de muligheden for en folkeafstemning om ti-femten år, når de ved hjælp af fredelige midler igen har vækket den sovende danske bevidsthed $i$ det fortyskede Slesvig med henblik pd en afstemning afholdt $i$ en tid, hoor de afgivne stemmer kan regnes for at være ægte. Hvor irriterende dette end må forekomme os, er deres uvillighed mod en umiddelbar befolkningsudveksling eller grænseændring altså ikke urimelig. " Denne vurdering var i det store og hele en gentagelse af, hvad udenrigsminister Gustav Rasmussen $\mathrm{i}$ månederne forud igen og igen havde udtrykt over for både FO i London og gesandt Randall under deres indbyrdes samtaler, og den rammer meget skarpt.

Gallop konkluderede i sin rapport: "Denne politik har ikke udsigt til at lykkes, grundet omstændigheder uden for vores kontrol - især beslutningerne truffet på Potsdamkonferencen. Men det synes vigtigt at anerkende fornuften $i$ den, og være lydhøre overfor danskernes onsker, og selv om vi ikke kan opfylde de fleste af dem, bør vi være sikre på, at vores grunde for dette bliver rigtigt forståede, og at prove at være imødekommende $i$ nogle sager, også selv om dette kommer til at koste os ekstra besvær, sålænge der 
ikke er overoældende grunde til ikke at gøre dette. " Danmark var en vigtig brik i Englands sfære på dette tidspunkt, og som Gallop selv påpegede, stod der også praktiske økonomiske interesser på spil: Danmark havde varer - landbrugsprodukter - som englænderne ville have.

Denne rapport lå $\mathrm{i}$ høj grad til grund for mødedagsordenen d. 7/8-1946.

Mødets sidste punkt hed: "IV. At diskutere mulig revision af vedtaget politik $i$ O.R.C. (45) 31. Skal danskerne nu sparges officielt om, hvad deres holdning er til en folkeafstemning med henblik på en grænseregulering nu, og samtidig fortælles, at hois de afslair dette, kan de ikke blande sig $i$ sydslesvigske affærer $i$ samme grad fremover? ${ }^{49}$ O.R.C. (45) 31 hentydede til principbeslutningen truffet $i$ kabinettet $i$ oktober $1945 . .^{50}$ Dengang var konklusionen, at der ikke var "tilstrækkelige grunde til en grænseændring ", samt at der ville være praktiske problemer forbundet med en evt. befolkningsudveksling, men at disse kunne overvindes, og at "der $i$ princippet ikke var indvendinger mod en sådan udvikling ..... ${ }^{51}$

På mødet lød konklusionen hvad angik en grænseregulering: "Effekten på tyskerne $i$ Slesvig-Holsten og $i$ den britiske zone som helhed ville være alvorlig, men dette måtte accepteres. Det var på den anden side af vital betydning at sorge for, at tyskerne [mindretallet, som jo bestod af tyske statsborgere] ikke troede, at de selv kunne bede om grænsexndringer, forslaget skulle komme fra den danske regering. ( $^{52}$ Det blev også fremhævet, at det slet ikke var utænkeligt, at der inden for 3-4 år i samme spor som hidtil ved en folkeafstemning ville være flertal $i$ befolkningen for en indlemmelse i Danmark. Det konstateredes endvidere, at »den nationalistiske bevægelse « i Danmark fandt stadig stigende stotte i befolkningen fra kongen og nedefter, og at danskerne trods dette ville være enstemmigt imod en befolkningsudveksling, samt at den danske regering på nuværende tidspunkt "formentlig « ikke ville kunne samle flertal for en omgående grænseregulering. Endvidere blev der ytret frygt for, at der snart $\mathrm{i}$ de allierede magters Kontrolråd ville blive stillet spørgsmål omkring det faktum at »en udenlandsk regering blandede sig $i$ tyske forhold «. Om de andre tre allierede magters holdning til Danmarks Sydslesvigpolitik vurderedes det, at "Russerne vil formentlig ikke støtte danskerne, skønt et hurtigt skift $i$ deres politik desangående ikke kan udelukkes. Franskmændene (på analogien Saar) vil muligvis stotte danskerne, og USA vil muligvis være lydhøre." Det blev i samme åndedrag foreslået, at England for at forebygge kritik fra de andre allierede selv kunne fremføre problemet $\mathrm{i}$ Kontrolrådet. 
I referatet hed det videre: "En grænserevision behover ikke være betinget af en folkeafstemning, der kan forhandles om den, og den vil indebære fraflytningen af flygtningene fra det meget lille område, der er tale om." Dette var en vigtig passus, som viser to ting. For det forste mente FO selv at kunne bestemme, hvor grænsen skulle ligge uden om de øvrige allierede. Ellers ville de ikke internt kunne fastlægge, under hvilke præmisser grænsen evt. skulle kunne ændres. For det andet viser omtalen af "det meget lille område der er tale om ", at man under alle omstændigheder ikke regnede med, at andet end en mindre grænseregulering kunne eller ville blive aktuel. En grænseregulering hvor hele Sydslesvig kom til Danmark, var der i alle tilfælde ikke tale om.

D. 12/8-1946 skrev FO-næstkommanderende Patrick Dean om den påtænkte note: "Det er essentielt, at vi snart afsender den for at generobre initiativet. Jeg forstår, at det er ministerens opfattelse, at Tysklands grænser på udenrigsministrenes møde $i$ Tyskland 1. november som noget af det forste vil blive diskuteret, og at han er meget ivrig efter at nå en aftale $i$ denne sag $n u$, for diskussionen om Tysklands fremtidige stilling begynder. « ${ }^{53}$ Derfor var det Dean meget magtpåliggende, at danskerne blev adspurgt så snart som overhovedet muligt. Dette tyder også på, at en grænseændring i dansk favør ikke var utopisk set fra britiske ønsker.

$\mathrm{Nu}$ var man i FO enige om den officielle Sydslesvigpolitik. Det har formentlig ikke været meningen, at der skulle gå over en måned fra noten blev formuleret, til den blev afleveret til den danske regering. Man havde $\mathrm{i}$ realiteten $\mathrm{i}$ et års tid fisket efter et endegyldigt dansk svar på, hvad Danmark onskede sig i Sydslesvig, men ikke været i stand til at fremtvinge et. Hvis Dean regnede med, at Tysklands fremtidige grænser skulle aftales $1 / 11-46$, kunne han ganske enkelt ikke længere leve med ikke at kende de danske intentioner. Selvom man kendte det danske Folketings politiske sammensætning, var det som om, man fra engelsk side ikke var helt sikker på, at danskerne ville afslå en grænserevision, når det med noten gik op for dem, at der var tale om et uigenkaldeligt "nu eller aldrig " tilbud. Og man ville være sikker på, at forholdet til Danmark ikke blev skadet af, at Danmark evt. senere ville bebrejde England, at man ikke havde fået tilbuddet om Sydslesvig. Ved mødet blev man også enige om, hvilken ordlyd noten til den danske regering skulle have, og skønt der inden den endelige aflevering en måned senere blev lavet kosmetiske ændringer, så blev indholdet reelt ikke ændret efter 7/8-1946. 
Burrows i FO sammenfattede to måneder senere i et brev til Healy (parlamentsmedlem) de engelske mål således: "Vores mål var at forsøge at få danskerne til at beslutte sig for, om de onskede at bede om et stykke af Tyskland eller en befolkningsudveksling, eller om de foretrak at lade Sydslesvigerne vedblive at være en del af Tyskland og den tyske befolkning. Vi ville væk fra den situation, hvor den danske regering folte, at de havde ret til at blande sig til sydslesvigernes fordel som et mindretal indenfor Tysklands grænser. $^{54}$

\section{Oktobernoten}

Det danske svar på septembernoten blev til i lange Folketingsforhandlinger, og blev efter vedtagelse d. 19/10-1946 overrakt til Dean i FO af den danske gesandt Eduard Reventlow d. 24/10-1946. I FO kommenterede Burrows d. 7/11-1946 svarnoten internt på denne måde: "Følgende er de essentielle punkter $i$ den danske note:

1. Den danske regering onsker hverken en grænseændring med eller uden folkeafstemning, eller en befolkningsudveksling.

2. De vil have kulturel og politisk frihed for de dansksindede på lige fod med den ikke-dansksindede del af befolkningen.

3. De tillægger det den største betydning at flygtningene $i$ området snarest fjernes.

4. De ønsker at være repræsenteret ved fremtidige internationale forhandlinger angående Tysklands fremtid.

5. De beder igen om en administrativ adskillelse af Sydslesvig fra Holsten.

6. De håber, at de kan fortsætte med frit at forhandle med den britiske regering $i$ alle sporgsmål angående den dansksindede befolkning $i$ Sydslesvig.

7. De har ikke $i$ sinde at foreslå nogen ændring $i$ Sydslesvigs nationale status, og overlader det til lokale befolkning at beslutte, om de vil rejse sporgsmålet om selvbestemmelse. «55

Punkt 1. mente han, »kræver ikke noget svar«, og af de 7 punkter han havde summeret op, var dette det vigtigste. Der havde været mange spekulationer omkring Sydslesvigs fremtid, både i Danmark og Sydslesvig, men så sandelig også i FO. Man havde længe været i tvivl om, hvad Danmarks intentioner egentlig var. Til sidst havde FO følt sig presset til nærmest at opfordre danskerne til at rejse spørgsmålet. Men nu havde man spurgt Danmark direkte, og man havde faet et 


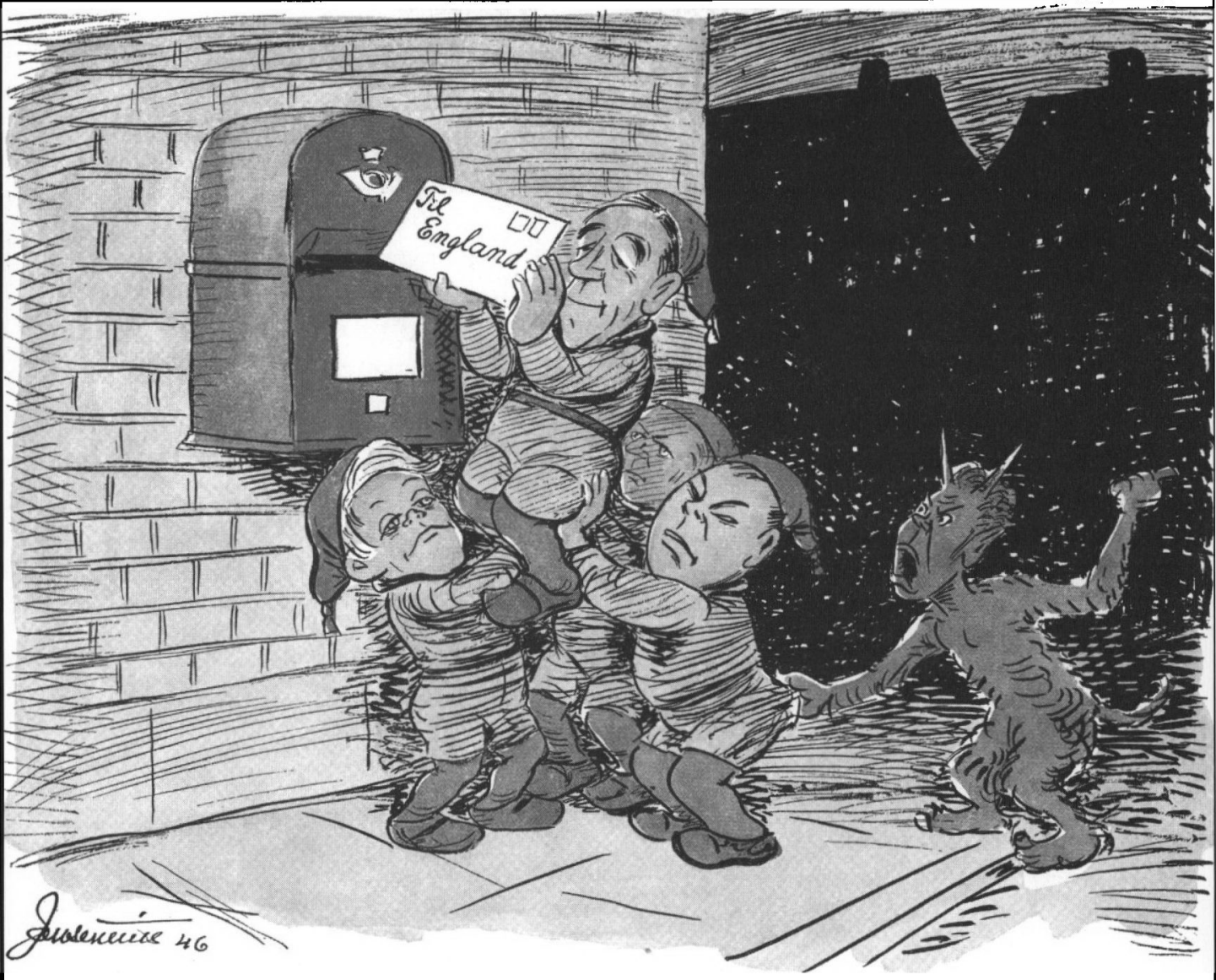

Knud Kristensen putter Oktobernoten i postkassen - sammen med Christmas Møller (Konservative) og Jørgen Jørgensen (Radikale). Aksel Larsen er ikke helt tilfreds med at socialdemokraten Hans Hedtoft hjælper til. Blæksprutten 1946.

svar, der ikke gav nogen tvivl om, at det klare flertal i Danmark var imod en grænserevision. Man behøvede ikke længere tænke i de baner.

Omkring punkt 3. - fjernelse af flygtningene i Sydslesvig - mente han, at danskerne bad om det umulige. Der var ikke mulighed for at fjerne flygtningene, og slet ikke efter at englænderne havde lovet at tage deres del af de tyske flygtninge i Danmark. Han udtrykte forståelse for den danske frygt for, at flygtningene kunne komme til at true Danmarks sikkerhed ved deres blotte antal, men konkluderede altså, at der ingen mulighed var for at ændre på situationen. Som lovet allerede $\mathrm{i}$ forbindelse med Rasmussens møde med Sargent $\mathrm{i}$ januar 1946 ville danskerne få mulighed for at "udtrykke deres synspunkter « ved den kommende fredskonference, konkluderede han. 
Omkring den administrative adskillelse af Sydslesvig fra Holsten skrev han, at det var det vanskeligste af de danske forslag at svare på, men at man - når man holdt fordele og ulemper op mod hinanden - måtte svare afvisende på følgende grundlag: En adskillelse ville medføre en dobbelt administration, og danskerne ville stadig være i klart mindretal i Sydslesvig alene. Endvidere ville Sydslesvig og Holsten alligevel blive lagt sammen igen, så snart tyskerne selv overtog styret. Og to så små enheder svarede ikke til den administrative struktur, man fra engelsk side forestillede sig for det fremtidige Tyskland.

Angående det sidste punkt specificerede han klart, at en evt. grænseændring skulle komme på foranledning af den danske regering: "Jeg tror ikke, vi kan acceptere den lokale befolknings ret til at rejse sporgsmålet om selvbestemmelse, når de har lyst til det. Tysklands grænser må fastsættes $i$ den meget nære fremtid, og vi kan ikke efterlade spørgsmålet om Sydslesvig åbent på ubestemt tid. ${ }^{56}$ Her kom englændernes principielle holdning klart til skue: Det var af hensyn til Danmark, at man var rede til at strække sig vidt i Sydslesvig. Det var ikke hensynet til lokalbefolkningen. Der var også en anden dimension: Det var i rollen som allieret og dermed som en af krigens sejrherrer, at Danmark kunne rejse spørgsmålet om Sydslesvigs fremtid. Man kunne blandt andet af præcedenshensyn ikke tillade, at lokalbefolkningen rundt omkring $\mathrm{i}$ det slagne Tyskland løsrev sig i mere eller mindre vilkårlige enheder.

Som konsekvens af den danske oktobernote konkluderede han: "Den generelle holdning må være, at vi har gjort vores bedste for at undgå at skabe et mindretal $i$ Tyskland, og give danskerne lov til at blande sig $i$ forholdene på den anden side af grænsen. Men danskerne synes at foretrække denne uløste sitiuation, som de synes giver dem det bedste af to verdener fremfor en klar beslutning, som en gang for alle ville bestemme, hvilke mennesker der var tyske, og hiilke der var danske. Det er klart, at vi ikke kan tvinge dem til at ændre grænsen eller til en befolkningsudveksling. En folkeafstemning nu ville være uretfærdig og urealistisk, og vi ønsker ikke at lade nogen tysk grænse være ubestemt for længere end højest nødvendigt for ikke at efterlade et håb om en senere folkeafstemning. Vi kan bruge den danske regerings afslag på en definitiv losning som grund til ikke at tillade dem at fortsætte med fortsat indblanding på sydslesvigernes vegne. Men vi bor ikke narre os selv til at tro, at vi $i$ praksis vil være $i$ stand til at standse den danske regering $i$ fortsat at betragte dette som et fuldt flyvefxrdigt mindre- 
talsspergsmål. ${ }^{57}$ Hermed havde han taget stilling til, hvad konsekvenserne af den danske note ville blive; danskerne onskede ikke Sydslesvig, ergo kunne man ikke påtvinge dem området - eller rettere en del deraf. Men der ville (efter al sandsynlighed) ikke komme flere muligheder. Tysklands fremtidige grænser skulle ikke stå og blafre i vinden.

Randall beskrev $i$ et brev til premierminister Clement Attlee $d$. 28/10-1946 den danske presses reaktioner på oktobernoten med disse ord: "Det synes som det er tilfældet med mange kompromisløsninger, at notens ordlyd er blevet rigeligt utydelig, for at tillade hvert parti at komme med dets egen fortolkning af den. De Konservative og Venstre betragter stadig muligheden for en fremtidig folkeafstemning som eksisterende. Det er stadig et äbent sporgsmal, om statsministeren vil gøre brug af notens dobbelttydighed som undskyldning for at fortsætte sin hidtidige politik. De Radikale benægter, at noten kan tolkes så ekstremt, men ikke så stærkt som Socialdemokratiet, som nu må fortryde, at de tillod statsministeren at lade noten inkludere selv denne meget vage hentydning til en fremtidig folkeafstemning. " 58 Ydermere skrev han, at det mest diskuterede punkt af noten i Danmark var det, der sagde, at det måtte være op til sydslesvigerne selv at rejse spørgsmålet om deres selvbestemmelse. Om denne ret vage formulering, som blev til for at skabe et kompromis mellem statsministeren og Socialdemokratiet, skrev han, at »de forskellige partier har naturligvis valgt at tolke den $i$ ret forskellige retninger «. Der blev i den danske presse spekuleret $\mathrm{i}$ - fremhævede han - at den sydslesvigske bevægelse, nu da den havde mistet den direkte støtte fra Danmark, muligvis ville søge at udvikle sig mere regionalt og lægge mere vægt på adskillelsen fra Holsten og resten af Tyskland end på en genforening med Danmark. Fra uofficielle kilder havde han hørt, at denne nyorientering rent faktisk var på vej blandt SSF's ledere.

Fra engelsk side forberedte man nu et svar på den danske oktobernote. Burrows orienterede 20/11-1946 Randall om, hvordan FO havde tænkt sig at svare den danske note. Han bad Randall om at få dennes synspunkter før det endelige svar blev sendt til den danske regering. Han skrev også, at Dean havde haft en samtale med Reventlow, umiddelbart før englænderne modtog oktobernoten. Her havde Dean sagt, at »vi var meget ivrige for at få eventuelt forslag til grænsemodifikationer $i$ god tid for udenrigsministermødet $i$ Tyskland «. Herom bemærkede Burrows nu, at danskerne naturligvis ikke ville blive nægtet den love- 

Englands Syn paa Svar-Noten:
Sagen ikke et Skridt videre

Man havde paa britisk Side ventet, tage Stilling til et af de tre

„Hvis Danmark ikke onsker Afgorelse nu, maa Sporgsmaalet senere blive dansk-tysk Anliggende -"

Fra vor Korrespondent

LONDON, Onsdag Aften.

TFTER Offentligg H. Sydalevig har man pan britisk Side formet sig et Forstehaundsindtryk, som indebarer Faren for en Skserpelse af den dansk-britiske Meningsudveksling: Man heveder, at den danske Note ikke har bragt Sagen et Skridt videre.

Det er lkke her spergsmealet on, hyorvidt det danake Svar er mere vidt- den blevet et sort Faar I de britianrwakende end Rigedagens Julierklo. Planer for Tyskland, og det konservaring. Det betydningstulde er, at man tuve Parti 1 storbritannien har fortra britisk side aynes at have ventet, Jengst peget paa, hvad det er, der er at Danmark vilde have taget stllling (i) et af do tre Alternativer.

Der hersker 1 London Enighed om, at Afanit ayv or den danake Notea vigtigate, men det er netop pan dette Punkt, Udenrigsministeriets Talsmand erklarer, at man Jkke kan udtale sig offictelt, for man grundigt har sat sig ind 1 Notens Indhold. En saadan offciel Udtalelse vil maaske kunne ventes senere, nelvom den danske Notes Form, saden som den optattes I Whitehall, ikke paakalder or direkte britisk svar. Alligevel er her den britlske Regeringn Syn nogenlunde klart: Naar Dunmark ikke enaker en Afgorelse mu, mait sporgomaalet oin on Afatemning sene. ro i hajere Grad blive et dansk-tysic Athiggende.

Dot er ingen Hommellghed, at Storbritanuien ensicer at stan $i$ ot godt Forhold thl et inyt demoleratial: Tyskland, og at wall derfor visor Uvilye mod at treffe Dispositioner, som nenere kan slaa Skwar i det fremtidige britisk-tyake Forhold. Man frygter agsaa, at Kravet om en senere Afstemining skal udvikle sig thl at abent Saar og affede permanent Uro i Bydsleavig til skade for det gode Forhold, som efter britisk Opfattelse formentlig ogsas Danmark essker at staa it til Fremtidens Tyskland. at Danmark vilde Alternativer

givet. Problemet vil blve lest, men det vil ske pas Iongere sigt, efterwom en Genopbygning af Industrt of Boltger kan inde sted 1 de tyske Industr. diatrikter.

En Opsummering af det brttiske Syn paa den danske Notes samlede Indhold giver det overraskende Resultat, at Briterne ikke aynes, at den or drastisk nok, og at Problemerne er kommet derea Losning mange Skridt neermere.

Danmark og de hollandske

\section{Krav}

Hertil vil man fra dansk Side ku haabe, at en mere grundig Gennemgang af Noten vil endre denne Opfattelise. Sammealignet med de drestiake Krav, som kan vented fra Hollands Side om Annektering of et tysk Grenseomraade med 400,000 tyoke Indbyggere, er chen danske Note et modorat Indlagg, a Problem, com naar alt kommer til alt angaar Danmark hojere Gred end Stortoritannien, der ikke selv har Gronser samme Karakter, acm den dansk-tyake.

Hvad Noten sandsynligvis vil resultere 1 , er, at Sydslesvigerne wil opnaa Indremmelser pas viase Punkter og Skutfelaer pae andre - og at det egentkg Slag om Syduleowig vil blive udksempet pas Konferencerne on den tyske Fredstralitat.

Gumar Howrikath.
I Nationaltidende fra 24. oktober 1946 kunne man lase en gengivelse af Englands syn på den danske Oktobernote: Da Danmark havde sagt nej til tilbuddet, var Sydslesvigspørgsmalet fremover henlagt til dreftelse mellem Danmark og Tyskland. 


\section{LITTERATUR}

Brondsted, G.K. (red.): Sydslesvig i dag. Den store Sydslesvig-Haandbog. Kobenhavn, 1955-1956.

van Campden, S.I.P.: The Quest for Security. Some Aspects of Netherlands Foreign Policy 1945-1950. Netherlands Institute of International Affairs, Martinus Nijhoff/The Hague, 1958.

Dethlefsen, Henrik og Lundbak, Henrik: "Fra mellemkrigstid til efterkrigstid «. I: Dethlefsen, Henrik og Lundbak, Henrik (udg.): Festskrift til Hans Kirchhoff og Henrik S. Nissen på 65-årsdagen oktober 1998. Museum Tusculanums Forlag, Københavns Universitet, 1998.

Frederiksen, Bjarne W.: Danmarks Sydslesvigpolitik efter det tyske sammenbrud i 1945. Dansk Udenrigspolitisk Institut, København og Århus, 1971.

Henningsen, Lars N., Klatt, Martin og Kühl, Jørgen: SSW, dansksindet politik i Sydslesvig 1945-1998. Studieafdelingen ved Dansk Centralbibliotek for Sydslesvig, Flensborg, 1998.

Leurdijk, J.H. (Red.): The Foreign Policy of the Netherlands. Sijthoff \& Noordhoff, Alphen aan den Rijn, 1978.

Mariager, Rasmus: Politik, Økonomi \& Kultur, Danmark og Storbritannien 1945-1947. Speciale, Institut for Historie, Kobenhavns Universitet, 1997.

Noack, Johan Peter: Det sydslesvigske grænsespørgsmål 1945-1947. Institut for Grænseregionsforskning, Aabenraa, 1991.

Rerup, Lorenz: Grænsen. Fra grænsekamp til sameksistens. Det udenrigspolitiske forlag, Albertslund, 1969.

Udenrigsministeriet. Aktstykker vedrørende det sydslesvigske Spørgsmaal, 1-3. København 1947-1950.

Wiggers, A.J., Lissens, R.F., Devreker, A., Kooy, G. A., Lauwerier, H. A. og Presser, J. (udg.): Grote Winkler Prins. Encyclopedie in twintig delen, deel 8 , G-Haai. Amsterdam, 1974.

\section{IKKE TRYKTE KILDER}

Public Record Office, London (PRO): Foreign Office, General Correspondence:
FO 371/47273， 55748-55763 (C688C15711), 56105, 56108.

Militærregeringen i Slesvig-Holsten: FO 1006/108, 208, 331, 711.

\section{NOTER}

1. Artiklen er en forkortet udgave af forfatterens speciale "Engelsk udenrigspolitik i det sydslesvigske spørgsmål 1945-46* (Kobenhavns Universitet, Institut for Historie, 2001). Specialet er tilgængeligt i Dansk Centralbibliotek for Sydslesvig.

2. "Sydslesvig i dag. Den store Sydslesvig-Haandbog “, 1955-1956 s. 422.

3. Noack, »Det sydslesvigske grænsespørgsmål 1945-1947«, 1991, s. 460 ff, og Udenrigsministeriet: "Aktstykker vedrørende det sydslesvigske spørgsmål «, I, 1947, s. 383 ff.

4. Noack, "Det sydslesvigske grænsespørgsmål 1945-1947 «, s. 450 ff.

5. 29/4-1946 var dette tal 310.500, hvoraf 180.000 var fra de gamle tyske områder nu inkorporeret i Polen, og 75.200 fra den russiske zone. 35.200 kom fra Hamburg, og 20.100 fra de 3 vestlige zoner af Tyskland. FO 371/ 55755/C8242.

6. PRO: FO 371/55748/C1026.

7. Hertil svarede Warner "at tiden nu, hvor grænser var under revision i forbindelse med fredsordningen, syntes at være det rette tidspunkt, om nogen sinde«. Noack, "Det sydslesvigske grænsespørgsmål 1945-1947 «, s. 275. Ifølge Noack blev hverken statsministeren eller regeringen orienteret om samtalen.

8. Ibid s. $277 \mathrm{ff}$.

9. PRO: FO 371/55750/C5589.

10. Noack, "Det sydslesvigske grænsespørgsmål 1945-1947«, s. 281 ff.

11. Aktstykker vedrorende det sydslesvigske Spergsmål, bd. 1. s. 365 .

12. Mange indberetninger fra Randall $i$ 1946 omkring forholdene i Danmark underbygger dette, f.eks. Randall til Bevin d. 15/5-46. PRO: FO 371/ $55750 / \mathrm{C} 5507$.

13. Der aftaltes faste priser over en læn- 
gere periode, f.eks. et år; problemet for Danmark og fordelen for Storbritannien ved sådanne aftaler var, at prisudviklingen $i$ almindelighed samt usikkerheden om kursen mellem pund og kroner på ingen markedsmæssig måde hang sammen med en fastprisaftale på landbrugsprodukter. Mariager, s. 54.

14. PRO: FO $371 / 55748 / \mathrm{C} 688$.

15. PRO: FO $371 / 55748 / \mathrm{C} 693$.

16. PRO: FO $371 / 55748 / C 1026$.

17. Begrebet "New Schleswigers" blev brugt af en engelsk lejtnant, Lynden Bell, omkring flygtningene. I en udtalelse i Kreistag'en for Sydtender fastslog han, at man lige så godt kunne se at få integreret flygtningene $i$ området, da der ingen udsigt var til, at de ville kunne vende hjem igen. Udtalelsen blev kendt i Danmark, og forårsagede et ramaskrig. PRO: FO 371/55750/C5545.

18. PRO: FO 371/55750/C4224.

19. PRO: FO $371 / 55750 / C 5507$.

20. PRO: FO $371 / 55750 / C 5590$.

21. PRO: FO 371/55752/C6656.

22. PRO: FO 371/55753/C7487, Randall til Bevin samme dag (1/7-46).

23. PRO: FO 371/55755/C8218.

24. "I am seriously concerned at the deterioration of our relations with Denmark owing to events in Germany. The change has come at a most inconvenient moment as we are just negotiating an agreement for a Danish division to participate in the occupation of Germany and for supply of British arms and equipment to Danish armed forces. We are also trying to clinch most important contracts for butter, bacon and other foodstuffs necessarily at prices which the Danes do not regard as remunerative - I therefore count on you to see that Danish questions in British Zone are handled with all possible sympathy for Danish susceptibilities so far as is possible within the scope of present policy. I trust that whenever we cannot meet their wishes, you will see that our case is fully and convincingly explained to them, either through our own publicity channels in Germany and the press or through His majesty's Legation in Copenhagen, so that reasonable and friendly Danes at least shall be persuaded that we are not treating their interests in a high-handed manner. PRO: FO 371/55755/C8218.

25. Se Mariager s. 52 ff. Endvidere Sargent til Steel 25/7-46, PRO: FO 371/ $55755 / \mathrm{C} 8218$.

26. Noack, „Det sydslesvigske grænsesporgsmål 1945-1947«, s. 237 ff.

27. PRO: FO $371 / 55755 / C 8219$.

28. PRO: FO 371/55753/C7521.

29. PRO: FO 371/55756/C9004.

30. PRO: FO $371 / 55756 / C 8868$.

31. PRO: FO 371/55762/C13281.

32. I have reason to think that an unofficial enquiry has been made of the Russians regarding their opinion on South Slesvig and that they replied to the effect that they sympathised with the Danish point of view and that the obvious solution was to purge Slesvig of all Germans, as the Poles had done in their spheres of interest. Without quoting me, it might be usefull to point out to the Danish Foreign Minister that the over-crowding of South Slesvig with Germans is the direct result of Russian and Polish policy. I am doing this here as opportunity offers.* PRO: FO 371/55748/C691.

33. PRO: FO 371/56108/N8277.

34. PRO: FO 371/55752/C6424.

35. PRO: FO $371 / 56108 / N 5298$.

36. Randall til Bevin 27/6-1946, PRO: FO $371 / 56108 / \mathrm{N} 8277$.

37. PRO: FO $371 / 56108 / N 8277$.

38. PRO: FO 371/55752/C6656.

39. Tale holdt i Folketinget $9 / 7-46$ som orientering omkring forholdene $i$ Sydslesvig. Gengivet i "Aktstykker vedrarende det sydslesvigske Spørgsmaal «, bd. 1, s. 284 ff.

40. PRO: FO 371/55752/C9767.

41. PRO: FO $371 / 55752 / C 6656$.

42. Den hollandske regering anlagde gennem hele forløbet en linie, der aktivt arbejdede for grænseregulering, meget modsat den passive danske grænsepolitik. Se f.eks. S.I.P. van Campden: "The Quest for Security “.

43. PRO: FO 371/55753/C7427.

44. Ibid.

45. PRO: FO 371/55753/C7487.

46. Gallop havde indtil 9/4-1940 giort tieneste på den britiske ambassade i Kobenhavn, deltog under krigen $\mathrm{i}$ opbygningen af SOE's danske sektion, og arbejdede i FO med danske 
spørgsmål. Noack, "Det sydslesvigske grænsespørgsmål 1945-1947«, s. 41.

47. PRO: FO 371/55759/C10053.

48. Tbid.

49. PRO: FO $371 / 55757 / C 9340$.

50. PRO: FO 371/55757/C9316.

51. PRO: FO 371/55757/C9340.
52. PRO: FO 371/55757/C9314.

53. PRO: FO 371/55757/C9314.

54. PRO: FO $371 / 55763 / \mathrm{C} 14126$.

55. PRO: FO $371 / 55762 / \mathrm{C} 12892$.

56. PRO: FO $371 / 55762 / \mathrm{C} 12892$.

57. Ibid.

58. PRO: FO $371 / 55763 / \mathrm{C} 13432$.

59. PRO: FO $371 / 55762 / C 12892$. 